\title{
Application of Elemental Geochemistry in High-Frequency Sequence-Stratigraphic Analysis of Lacustrine Shale
}

\author{
Hongliang Wang ${ }^{1,2,3, *}$, Zehua Zhang ${ }^{1,2,3}$, Jintong Liang ${ }^{4}$, Huimin Liu ${ }^{5}$ and Shige Shi ${ }^{5}$ \\ 1 School of Energy Resources, China University of Geosciences (Beijing), Beijing 100083, China; \\ 2106170055@cugb.edu.cn \\ 2 Key Laboratory of Marine Reservoir Evolution and Hydrocarbon Accumulation Mechanism, \\ Ministry of Education, China University of Geosciences (Beijing), Beijing 100083, China \\ 3 Beijing Key Laboratory of Unconventional Natural Gas Geological Evaluation and Development Engineering, \\ China University of Geosciences (Beijing), Beijing 100083, China \\ 4 Institute of Sedimentary Geology, Chengdu University of Technology, Chengdu 610059, China; \\ jtlcugb@126.com \\ 5 Shengli Oilfield Company, SINOPEC, Dongying 257000, China; hmliu@vip.163.com (H.L.); \\ shishige266.slyt@sinopec.com (S.S.) \\ * Correspondence: Whliang@cugb.edu.cn
}

check for updates

Citation: Wang, H.; Zhang, Z.; Liang, J.; Liu, H.; Shi, S. Application of Elemental Geochemistry in HighFrequency Sequence-Stratigraphic Analysis of Lacustrine Shale. Minerals 2021, 11, 657. https://doi.org/ $10.3390 / \min 11060657$

Academic Editor: Alvar Soesoo

Received: 13 April 2021

Accepted: 18 June 2021

Published: 21 June 2021

Publisher's Note: MDPI stays neutral with regard to jurisdictional claims in published maps and institutional affiliations.

Copyright: (c) 2021 by the authors. Licensee MDPI, Basel, Switzerland. This article is an open access article distributed under the terms and conditions of the Creative Commons Attribution (CC BY) license (https:// creativecommons.org/licenses/by/ $4.0 /)$.

\begin{abstract}
The successful development of shale gas and oil in North America has created considerable interest in shale. The analysis of genetic types, the sedimentary environment, and the mudstone development mechanism within sequences is critical for evaluating shale gas and oil exploration prospects, exploration favorable zones, and resource potential. This study focused on the shale of Shahejie Formation in Dongying Depression of Bohai Bay Basin. Shale lithofacies division, geochemical analysis, and well-log analysis were performed for a sedimentary environment and its related elemental response characteristics' identification. Based on the results, we concluded that the sedimentary environment of the lake basin evolved from the saltwater lake to the ambiguous lake and then the open lake to the delta. In response, we observed gradually decreasing $\mathrm{Sr} / \mathrm{Ba}$ and $\mathrm{Ca} / \mathrm{Mg}$ ratios and increasing $\mathrm{Rb} / \mathrm{Ca}$ and $\mathrm{Fe} / \mathrm{Mn}$ ratios during the whole process during the reduction of the salinity and the decrease in PH value and sediments' transport distance. The relationship between ratio elements and high-frequency sequences was initially established within the shale strata. Our results show that ratios of $\mathrm{Sr} / \mathrm{Ba}$ and $\mathrm{Ca} / \mathrm{Mg}$ ratios near the sequence boundary are relatively low, and ratios of $\mathrm{Fe} / \mathrm{Mn}$ and $\mathrm{Rb} / \mathrm{Ca}$ are relatively high, while ratios of $\mathrm{Sr} / \mathrm{Ba}$ and $\mathrm{Ca} / \mathrm{Mg}$ near the flooding surface are relatively high, and ratios of $\mathrm{Fe} / \mathrm{Mn}$ and $\mathrm{Rb} / \mathrm{Ca}$ are relatively low. Those features can be used as a marker for high-frequency sequence division of shale strata. Our results provided a new theoretical basis and technical method for shale gas and oil exploration and development.
\end{abstract}

Keywords: lacustrine shale; high-frequency sequence; geochemical characteristics; elemental geochemistry; combination of elements

\section{Introduction}

The analysis of genetic types, the sedimentary environment, and the mudstone development mechanism within sequences is critical for evaluating shale gas and oil exploration prospects, exploration favorable zones, and resource potential. In the past, shale was only studied as a source rock for hydrocarbon exploration. Most sedimentologists believed that the changes within mudstone formation are negligible. Mudstone in outcrop or core observation in geologic study was simply defined as "massive mudstone" and "rich organic mudstone" or "oil shale" [1]. Due to the successful development of shale gas and oil in recent years, shale has attracted great interest as a reservoir formation for researchers [2].

Studies have been performed on the sedimentary environment, sediment origins, rock type, and characteristics of shale [1,3-10]. In recent years, the sequence stratigraphy of 
shale has also been analyzed in various countries. Those studies concluded that even in an environment favorable to organic matter accumulation, the properties and distribution of source rocks underwent systemic changes both vertically and laterally. This change can be laminae to the super-sequence and range from a few centimeters to thousands of meters [11-19]. The change is controlled by the sedimentary environment and stratigraphic stacking patterns and exists in both sequence and para-sequence scales. Para-sequence is the basic unit of describing organic matter enrichment, and the internal rock properties (or litho-faces/facies) of the para-sequence also underwent systematic changes [20].

Previous studies have shown that shale formation division has a unique correlation with its sequence hierarchy $[4,10]$. The $\mathrm{m}$ promising exploration of shale sections developed in the transgression stage of the second-order sequence. For basins with a high amount of allochthonous sediment supply, good reservoirs with storage particles are mainly formed in the high or low stand in system tracts within the third-order sequence. For basins with significant internal biogenic substances deposited, the best reservoirs are usually developed in the condensed sections of the third-order sequence [21].

In previous research, the high-frequency sequence division of the lake-facies sediments was mainly in the deposition of coarse debris sediments. Coarse-grained sediment has obvious lithologic changes, which made it easy for progradation and retrogradation identification and high-frequency sequence division. However, the division of shale sequence stratigraphy (especially high-frequency sequence) is difficult to carry out and a difficult point in the study of high-frequency sequence.

The index of elemental geochemistry has now been a successful indicator for marine and lake environments. The difference in elemental geochemical parameters is a reflection of shale lithofacies and the sedimentary environment [22-24]. Guo et al. (2015) found that lake-water depth changes from deep to shallow in a high-frequency sequence unit, and ratios of elements in shales show regular change accordingly, especially in the high-frequency cycle interface. Consequently, the periodical vertical variation of organic geochemical parameters provides a basis for sequence stratigraphic unit classification and correlation in the lacustrine basin. Jin, Han, Wang, Guo, and Gao (2008) [25] found good correlations between the vertical change of geochemical elements and para-sequence cycle changes in lake-facies shales, and the cyclic change of the geochemical element can also be used for the classification of high-frequency sequences' stratigraphy division in shales. Their study specified the significance of using geochemical elements in high-frequency shale sequence stratigraphy division study and has great significance for shale gas and oil exploration and development.

Our study focused on sequence stratigraphy of shale in the third member of Shahejie Formation in the Dongying Depression of the Bohai Bay Basin. We analyzed high-frequency sequence stratigraphy of lacustrine shale using elemental geochemistry. The Shahejie Formation in the Dongying Depression is enriched in organic matter and has good potential for shale gas and oil reservoirs [26]. The lithofacies classification, sedimentary environment, and elemental characteristics of shale were carried out based on observation and description of cores and analysis of laboratory data. Combining geochemical elements analysis results, the relationship between ratios of elements and high-frequency sequence stratigraphy is initially vertical in the whole formation. Our study provided a good example and basis for the high-frequency sequence division in shale and could be a guidance for the exploration and development of shale gas and oil.

\section{Data and Methods}

Our research included macroscopic core description, sedimentary environment analysis technology, high-frequency sequence stratigraphic analysis technology, element phase analysis, and element ratio analysis technology.

Our study analyzed $600 \mathrm{~m}$ long cores of Well Niu 38 in the Dongying depression of the Bohai Bay Basin. There are 2390 samples in our study for elemental analysis; 73 samples were used for total organic carbon (TOC) analysis, and 42 samples were used for vitrinite 
reflectance (Ro) values from five studied wells. Geochemical elements' contents and ratios were analyzed using atomic absorption spectrometry. TOC contents were detected by a carbon-sulfur analyzer (Leco444). Ro values were tested using a microscope photometer (UMSP-50). All the analyses were performed in the Geological Research Institution Center at Shengli Oil field.

\section{Results and Discussions}

Overall, sediments are dominated by fine-grained sedimentary rocks in the middle and lower parts of the third member of Shahejie formation in the study area. Dark grey mudstones and calcareous mudstones constitute multiple couples. Thin $(<10 \mathrm{~cm})$ grey fine-grained sandstones are deposited in the lower part of the third member of the Shahejie formation. In the middle part of the third member of the Shahejie formation, sediments are dominated by dark grey mudstone and silty mudstone couples. The middle strata contain much more sand than the lower strata do. Thin $(<10 \mathrm{~cm})$ gray muddy sandstones, thin $(<10 \mathrm{~cm})$ gray muddy siltstones, thin $(<10 \mathrm{~cm})$ gray fine-grained sandstones, and calcareous mudstones are shown. Elemental ratios can be used to divide the sequence of fine-grained sedimentary rocks.

\subsection{Elemental Ratios}

Elemental Ratios as Indicators for Facies

In this study, the ratios of $\mathrm{Sr} / \mathrm{Ba}, \mathrm{Ca} / \mathrm{Mg}, \mathrm{Fe} / \mathrm{Mn}$, and $\mathrm{Rb} / \mathrm{Ca}$ were selected as indicators for facies changes. Those ratios could be used to indicate physical and chemical conditions such as water salinity and sediment transport distance [27-29]. The ratios have different features (Figure 1, Table S1).

Sr/Ba: Sr and Ba can both form soluble bicarbonates and sulfates dissolved into aqueous solutions. The solubility of Ba-containing compounds and salts is relatively low, which made the migration capacity of Ba significantly lower than that of Sr [10,27]. Deng and Qian (1993) [10] provided a classification regarding the ability of element migration, which decreased in the order: Type I, Type II, and Type III. In our studied area, Sr is the most easily migrated element and classified as Type I. Ba is classified as Type III, which is difficult to migrate. The high content of $\mathrm{Sr}$ is related to the salinity of the lake. Salinity increased as the sediment changed from shore to deep water, so $\mathrm{Sr} / \mathrm{Ba}$ ratio can be a good sign of the salinity of the water medium.

$\mathrm{Ca} / \mathrm{Mg}$ : The content of $\mathrm{Ca}$ in lacustrine shale in our studied layer is higher than that of $\mathrm{Mg}$, and the content of $\mathrm{Ca}$ in lacustrine shale is significantly higher than that of fluvial facies shale. The solubility of calcium salt and magnesium salt varies in the lake. According to the principle of sedimentation differentiation, magnesium salt is more difficult to deposit compared to calcium salt, and the precipitation of $\mathrm{Ca}$ is more significantly affected by the acidity and alkalinity of the water medium. Therefore, the $\mathrm{Ca} / \mathrm{Mg}$ ratio in lacustrine shale is significantly higher than in the fluvial facies shale. In lacustrine shale, the ratio of $\mathrm{Ca} / \mathrm{Mg}$ can be used as a sign to indicate acidity and alkalinity in the water medium.

Fe/Mn: The difference between the geochemical properties of Fe and Mn determines their differentiation in the sediment transportation process. Fe-containing compounds are easier to gather in coastal areas, while Mn has the highest content in brackish-salt intermittent occlusion-occlusion of the lake. Therefore, Fe/Mn ratio can be used as a sign of offshore distance (or depth). Some research results have shown that the Fe/Mn ratio is related to salinity and decreases with salinity [10].

$\mathrm{Rb} / \mathrm{Ca}: \mathrm{Rb}$ can be adsorbed by clay minerals and is enriched in sand and mudstone but poor in carbonate rocks, which makes the ratio of $\mathrm{Rb}$ and $\mathrm{Ca}$ in sediment have a clear negative correlation. Therefore, the ratio of $\mathrm{Rb} / \mathrm{Ca}$ can clearly indicate the lake regression and aggression process due to the delta's progradation and retrogradation. Due to the increase in the composition of terrestrial sand and mud because of regression, the ratio of $\mathrm{Rb} / \mathrm{Ca}$ is high during the retrogression of the lake. During the transgression of the lake, the $\mathrm{Rb} / \mathrm{Ca}$ ratio is low, because the carbonate content increased due to the alkalinity of 
the medium. Therefore, the $\mathrm{Rb} / \mathrm{Ca}$ ratio can be used as an indirect symbol of the distance to offshore.

In our study, five different wells were selected, each of them located in places with different sedimentary environments. There are also large differences in the types of shale generated from different sedimentary environments, which also proved that the difference in the geochemical properties of the elements reflects the genesis and sedimentary environment of the shale (Figure 2).

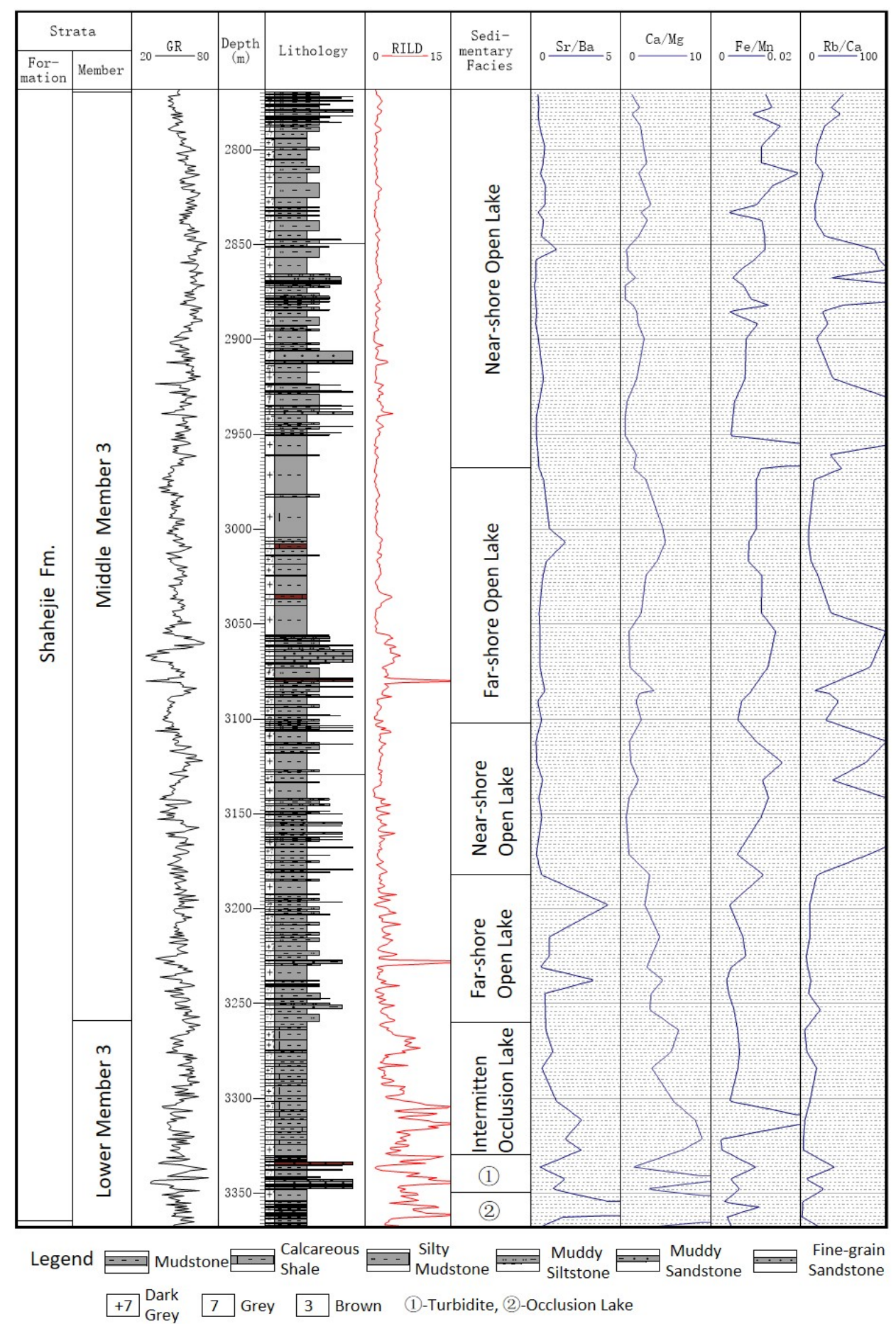

Figure 1. Longitudinal variation of element ratio in Well Niu 38, Dongying Depression. 


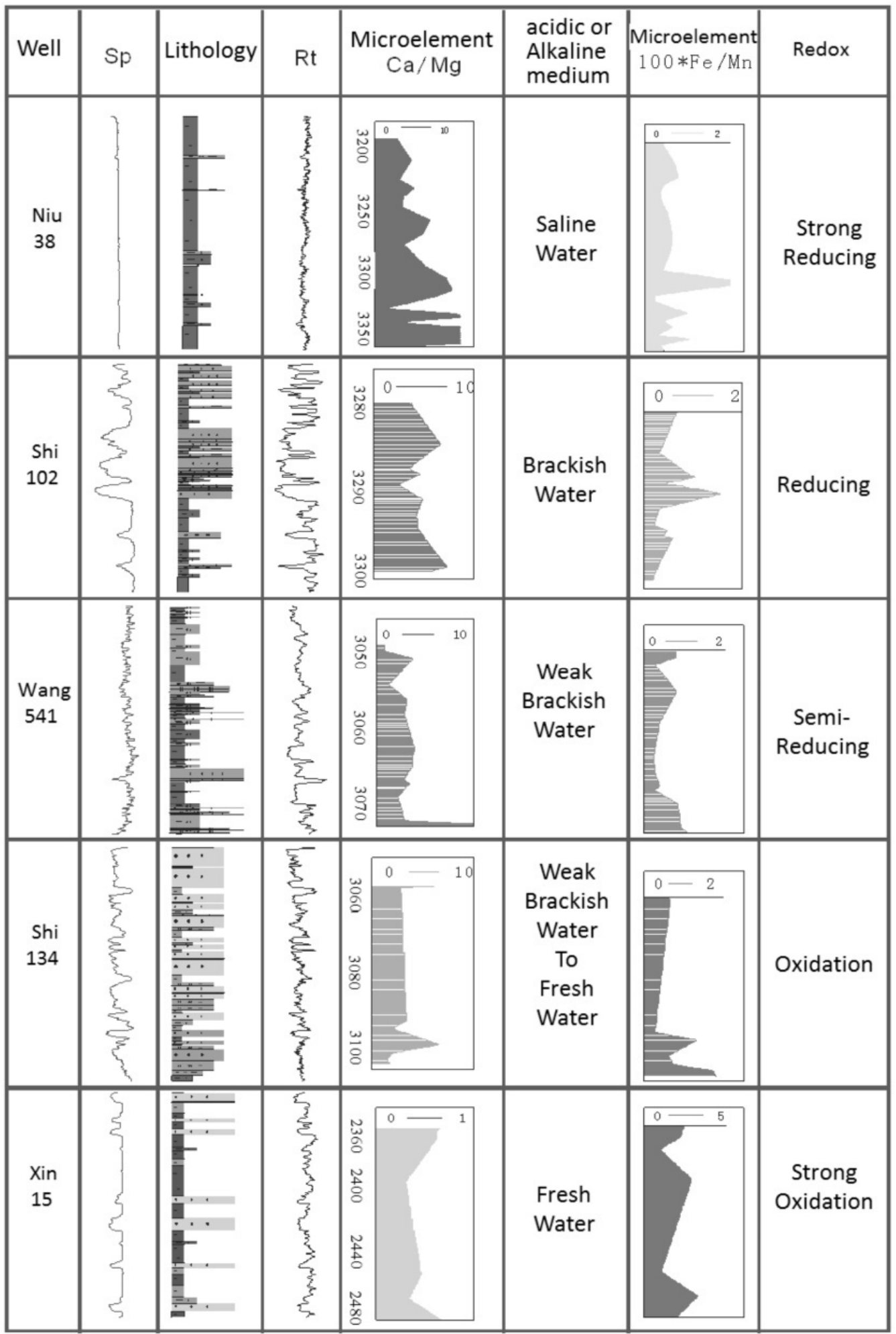

Figure 2. Variation of element ratios in different sedimentary environments of shale in Dongying Depression.

\subsection{TOC Changes in Different Lake Shale Sediments}

The organic matter abundance of different sedimentary facies can be very different (Table 1) [10]. In the third Middle Member of Shahejie Formation, the organic matter content of shales deposited in the blocked lake was $2.55 \%$ on average. However, in the third Lower Member of Shahejie Formation, the organic matter content of shales in the open 
lake is $2.93 \%$ on average. The occluded lacustrine facies are more organic-matter-enriched than the open lake facies. The content of organic matter in saltwater lake facies is no less than that of freshwater and brackish water lake facies. In the same saltwater lake, the shale deposit during the relative desalination period in deep water was higher in organic matter content than the gray mudstone deposit during the relative salination period in shallow water. Similarly, in freshwater facies, the mudstone in the open lake far from the shore is higher in organic matter content than the mudstone in the open lake facies on shore (Figure 3; Tables 2 and 3).

Table 1. TOC contents of lacustrine mudstones in different sedimentary facies (modified after Deng and Qian, 1993 [10]).

\begin{tabular}{|c|c|c|c|c|c|c|}
\hline \multirow{2}{*}{ Scheme } & \multirow{2}{*}{$\begin{array}{l}\text { Un-Occlusive } \\
\text { Lake }\end{array}$} & \multirow{2}{*}{$\begin{array}{l}\text { Occlusive } \\
\text { Lake }\end{array}$} & \multirow{2}{*}{$\begin{array}{c}\text { Intermittent } \\
\text { Occlusive Lake }\end{array}$} & \multicolumn{2}{|c|}{ Open Lake } & \multirow{2}{*}{$\begin{array}{l}\text { Turbidity } \\
\text { Mudstone }\end{array}$} \\
\hline & & & & Far Shore & Near Shore & \\
\hline Lithofacies & Gray Mudstone & Black Shale & $\begin{array}{l}\text { Calcareous } \\
\text { Laminas Shale }\end{array}$ & $\begin{array}{c}\text { Even Massive } \\
\text { Mudstone Horizontally } \\
\text { Bedded Mudstone }\end{array}$ & $\begin{array}{c}\text { Gray } \\
\text { Mudstone }\end{array}$ & $\begin{array}{l}\text { Uneven } \\
\text { Massive } \\
\text { Mudstone }\end{array}$ \\
\hline TOC (\%) & $\frac{2.3}{0.59-3.86}$ & $\frac{3.5}{2.11-5.7}$ & $\frac{2.8}{2.73-3.00}$ & $\frac{1.6}{1.01-1.97}$ & $\frac{0.9}{0.46-1.37}$ & $\frac{0.5}{0.46-0.51}$ \\
\hline
\end{tabular}

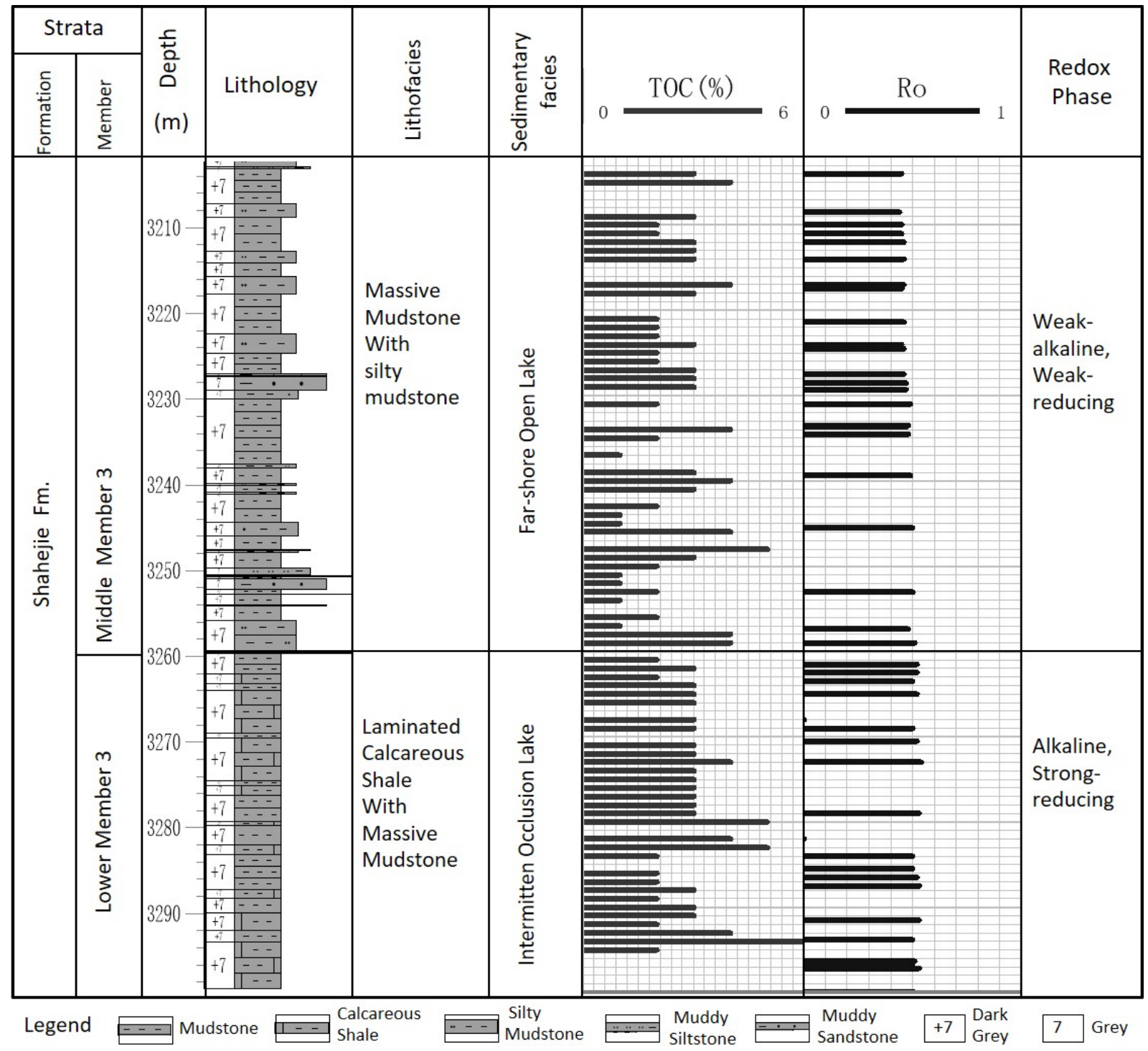

Figure 3. TOC content changes in different lithofacies and sedimentary environments in Well Niu 38, Dongying. 
Table 2. TOC contents of shale samples from well Niu 38.

\begin{tabular}{|c|c|c|c|c|c|c|c|c|}
\hline Sample & Depth (m) & TOC (\%) & Sample & Depth (m) & TOC (\%) & Sample & Depth (m) & TOC (\%) \\
\hline 1 & 3203.0 & 4.0 & 29 & 3239.7 & 3.2 & 57 & 3273.2 & 4.0 \\
\hline 2 & 3204.1 & 2.1 & 30 & 3240.1 & 1.9 & 58 & 3274.1 & 3.2 \\
\hline 3 & 3204.6 & 2.9 & 31 & 3241.0 & 3.1 & 59 & 3275.6 & 3.1 \\
\hline 4 & 3205.1 & 3.9 & 32 & 3243.2 & 2.0 & 60 & 3276.3 & 3.0 \\
\hline 5 & 3209.0 & 3.0 & 33 & 3244.3 & 1.2 & 61 & 3277.2 & 2.2 \\
\hline 6 & 3210.2 & 2.1 & 34 & 3245.8 & 1.3 & 62 & 3277.8 & 3.1 \\
\hline 7 & 3211.1 & 2.0 & 35 & 3246.5 & 4.2 & 63 & 3278.5 & 2.9 \\
\hline 8 & 3212.3 & 3.1 & 36 & 3248.0 & 5.0 & 64 & 3279.4 & 2.0 \\
\hline 9 & 3213.2 & 2.9 & 37 & 3249.1 & 3.3 & 65 & 3279.9 & 3.1 \\
\hline 10 & 3214.6 & 2.9 & 38 & 3250.2 & 2.1 & 66 & 3280.2 & 2.0 \\
\hline 11 & 3217.1 & 3.0 & 39 & 3251.5 & 1.1 & 67 & 3280.7 & 4.9 \\
\hline 12 & 3217.5 & 4.0 & 40 & 3252.4 & 1.3 & 68 & 3282.1 & 1.1 \\
\hline 13 & 3218.9 & 3.1 & 41 & 3253.3 & 2.0 & 69 & 3282.7 & 4.0 \\
\hline 14 & 3221.2 & 2.2 & 42 & 3254.0 & 1.3 & 70 & 3283.2 & 2.2 \\
\hline 15 & 3222.3 & 2.1 & 43 & 3256.5 & 2.2 & 71 & 3283.8 & 5.0 \\
\hline 16 & 3223.5 & 2.2 & 44 & 3257.3 & 1.1 & 72 & 3284.3 & 1.3 \\
\hline 17 & 3224.4 & 3.0 & 45 & 3258.1 & 4.0 & 73 & 3284.9 & 2.0 \\
\hline 18 & 3225.6 & 2.1 & 46 & 3259.1 & 3.9 & 74 & 3286.2 & 2.2 \\
\hline 19 & 3226.6 & 2.3 & 47 & 3261.0 & 2.2 & 75 & 3287.3 & 2.4 \\
\hline 20 & 3227.2 & 2.9 & 48 & 3262.1 & 3.1 & 76 & 3288.5 & 3.0 \\
\hline 21 & 3228.3 & 1.2 & 49 & 3263.3 & 2.2 & 77 & 3289.2 & 2.1 \\
\hline 22 & 3228.7 & 2.9 & 50 & 3264.2 & 3.0 & 78 & 3290.4 & 2.3 \\
\hline 23 & 3229.2 & 2.2 & 51 & 3265.1 & 3.1 & 79 & 3290.9 & 3.1 \\
\hline 24 & 3229.8 & 3.0 & 52 & 3266.4 & 3.2 & 80 & 3291.6 & 2.9 \\
\hline 25 & 3231.2 & 2.1 & 53 & 3268.7 & 3.3 & 81 & 3292.3 & 2.2 \\
\hline 26 & 3234.3 & 3.9 & 54 & 3269.3 & 3.0 & 82 & 3293.2 & 3.0 \\
\hline 27 & 3235.6 & 1.9 & 55 & 3271.2 & 3.2 & 83 & 3293.8 & 4.2 \\
\hline 28 & 3237.8 & 1.1 & 56 & 3272.5 & 3.3 & 84 & 3294.6 & 6.0 \\
\hline
\end{tabular}

It can be concluded that the lake water stratification is beneficial for the accumulation and preservation of organic matter, and therefore the organic matter abundance of mudstone is high. The reason is that the salt layer of the lake prevents the water circulation between the surface and the bottom of the lake; therefore, a strong anoxic reduction environment is formed at the bottom. In the large-body saltwater lakes at deeper desalination periods, due to the presence of salt transitions, the bottom water is in a strong reduction environment. The change in salinity resulting in biological cyclic death and reproduction can provide abundant raw material of organic matter, resulting in high organic matter content. When the water depth of the lake decreases, the increased hydrodynamic energy and weak reduction conditions can damage the storage of organic matter, which will reduce the abundance of organic matter content. 
Table 3. Ro values of shale samples from well Niu 38. M. = Middle, L. = Lower.

\begin{tabular}{|c|c|c|c|c|c|c|c|}
\hline Sample & Depth (m) & For & Ro (\%) & Sample & Depth (m) & For. & Ro $(\%)$ \\
\hline 1 & 2771.00 & Es3 & 0.67 & 71 & 3197.74 & Es3 & 0.44 \\
\hline 2 & 2777.65 & Es3 & 0.42 & 72 & 3204.00 & M. Es3 & 0.45 \\
\hline 3 & 2784.70 & Es3 & 0.50 & 73 & 3208.50 & M. Es3 & 0.44 \\
\hline 4 & 2798.17 & Es3 & 0.48 & 74 & 3209.92 & Es3 & 0.45 \\
\hline 5 & 2804.40 & Es3 & 0.43 & 75 & 3211.00 & M. Es3 & 0.45 \\
\hline 6 & 2815.23 & Es3 & 0.60 & 76 & 3212.00 & M. Es3 & 0.46 \\
\hline 7 & 2828.70 & Es3 & 0.52 & 77 & 3214.00 & M. Es3 & 0.46 \\
\hline 8 & 2836.54 & Es3 & 0.52 & 78 & 3217.00 & M. Es3 & 0.46 \\
\hline 9 & 2843.60 & Es3 & 0.64 & 79 & 3217.50 & M. Es3 & 0.45 \\
\hline 10 & 2857.27 & Es3 & 0.75 & 80 & 3221.38 & Es3 & 0.46 \\
\hline 11 & 2874.88 & Es3 & 0.81 & 81 & 3224.00 & M. Es3 & 0.45 \\
\hline 12 & 2898.72 & Es3 & 0.77 & 82 & 3224.50 & M. Es3 & 0.46 \\
\hline 13 & 2901.02 & Es3 & 0.56 & 83 & 3227.50 & M. Es3 & 0.46 \\
\hline 14 & 2918.50 & Es3 & 0.69 & 84 & 3228.50 & M. Es3 & 0.47 \\
\hline 15 & 2926.00 & Es3 & 0.48 & 85 & 3229.30 & M. Es3 & 0.47 \\
\hline 16 & 2943.00 & Es3 & 0.70 & 86 & 3231.00 & M. Es3 & 0.49 \\
\hline 17 & 2944.81 & Es3 & 0.39 & 87 & 3233.50 & M. Es3 & 0.48 \\
\hline 18 & 2951.40 & Es3 & 0.62 & 88 & 3233.71 & Es3 & 0.47 \\
\hline 19 & 2952.80 & Es3 & 0.49 & 89 & 3234.50 & M. Es3 & 0.48 \\
\hline 20 & 2953.40 & Es3 & 0.51 & 90 & 3239.42 & Es3 & 0.49 \\
\hline 21 & 2954.20 & Es3 & 0.58 & 91 & 3245.50 & M. Es3 & 0.50 \\
\hline 22 & 2955.60 & Es3 & 0.45 & 92 & 3253.04 & Es3 & 0.50 \\
\hline 23 & 2958.65 & Es3 & 0.43 & 93 & 3257.40 & M. Es3 & 0.48 \\
\hline 24 & 2960.15 & Es3 & 0.44 & 94 & 3259.00 & M. Es3 & 0.51 \\
\hline 25 & 2960.50 & Es3 & 0.48 & 95 & 3261.50 & M. Es3 & 0.50 \\
\hline 26 & 2962.15 & Es3 & 0.51 & 96 & 3261.54 & Es3 & 0.52 \\
\hline 27 & 2964.15 & Es3 & 0.54 & 97 & 3262.50 & M. Es3 & 0.52 \\
\hline 28 & 2966.15 & Es3 & 0.51 & 98 & 3263.50 & M. Es3 & 0.50 \\
\hline 29 & 2967.55 & Es3 & 0.47 & 99 & 3265.00 & M. Es3 & 0.52 \\
\hline 30 & 2969.05 & Es3 & 0.59 & 100 & 3269.00 & M. Es3 & 0.50 \\
\hline 31 & 2969.40 & Es3 & 0.46 & 101 & 3270.50 & M. Es3 & 0.52 \\
\hline 32 & 2971.05 & Es3 & 0.62 & 102 & 3273.00 & M. Es3 & 0.54 \\
\hline 33 & 2973.85 & Es3 & 0.47 & 103 & 3279.00 & M. Es3 & 0.53 \\
\hline 34 & 2974.60 & Es3 & 0.62 & 104 & 3284.00 & L. Es3 & 0.50 \\
\hline 35 & 2977.75 & Es3 & 0.42 & 105 & 3285.50 & L. Es3 & 0.50 \\
\hline 36 & 2991.77 & Es3 & 0.61 & 106 & 3286.50 & L. Es3 & 0.52 \\
\hline 37 & 2994.47 & Es3 & 0.53 & 107 & 3287.50 & L. Es3 & 0.53 \\
\hline 38 & 3001.30 & Es3 & 0.35 & 108 & 3291.50 & L. Es3 & 0.53 \\
\hline 39 & 3001.43 & Es3 & 0.56 & 109 & 3293.80 & L. Es3 & 0.50 \\
\hline 40 & 3004.40 & Es3 & 0.57 & 110 & 3296.30 & L. Es3 & 0.51 \\
\hline 41 & 3010.73 & Es3 & 0.52 & 111 & 3296.93 & Es3 & 0.50 \\
\hline
\end{tabular}


Table 3. Cont.

\begin{tabular}{|c|c|c|c|c|c|c|c|}
\hline Sample & Depth (m) & For & Ro (\%) & Sample & Depth (m) & For. & Ro $(\%)$ \\
\hline 42 & 3020.60 & Es3 & 0.44 & 112 & 3297.20 & L. Es3 & 0.53 \\
\hline 43 & 3023.50 & Es3 & 0.66 & 113 & 3300.00 & L. Es3 & 0.51 \\
\hline 44 & 3026.50 & Es3 & 0.43 & 114 & 3302.10 & L. Es3 & 0.54 \\
\hline 45 & 3032.50 & Es3 & 0.49 & 115 & 3304.40 & L. Es3 & 0.53 \\
\hline 46 & 3038.81 & Es3 & 0.36 & 116 & 3307.80 & L. Es3 & 0.53 \\
\hline 47 & 3039.80 & Es3 & 0.40 & 117 & 3309.66 & Es3 & 0.49 \\
\hline 48 & 3040.81 & Es3 & 0.52 & 118 & 3311.50 & L. Es3 & 0.51 \\
\hline 49 & 3045.88 & Es3 & 0.54 & 119 & 3313.50 & L. Es3 & 0.50 \\
\hline 50 & 3047.88 & Es3 & 0.51 & 120 & 3317.00 & L. Es3 & 0.53 \\
\hline 51 & 3049.88 & Es3 & 0.52 & 121 & 3319.07 & Es3 & 0.53 \\
\hline 52 & 3051.00 & Es3 & 0.45 & 122 & 3320.30 & L. Es3 & 0.54 \\
\hline 53 & 3053.68 & Es3 & 0.46 & 123 & 3321.60 & L. Es3 & 0.51 \\
\hline 54 & 3054.68 & Es3 & 0.45 & 124 & 3324.20 & L. Es3 & 0.51 \\
\hline 55 & 3055.58 & Es3 & 0.58 & 125 & 3328.00 & L. Es3 & 0.51 \\
\hline 56 & 3072.50 & Es3 & 0.57 & 126 & 3329.53 & Es3 & 0.53 \\
\hline 57 & 3076.60 & Es3 & 0.56 & 127 & 3330.70 & L. Es3 & 0.51 \\
\hline 58 & 3088.40 & Es3 & 0.61 & 128 & 3332.20 & L. Es3 & 0.00 \\
\hline 59 & 3090.50 & Es3 & 0.57 & 129 & 3337.00 & L. Es3 & 0.50 \\
\hline 60 & 3091.73 & Es3 & 0.64 & 130 & 3339.70 & L. Es3 & 0.45 \\
\hline 61 & 3096.02 & Es3 & 0.65 & 131 & 3340.90 & Es3 & 0.47 \\
\hline 62 & 3098.80 & Es3 & 0.62 & 132 & 3341.30 & Es3 & 0.53 \\
\hline 63 & 3109.22 & Es3 & 0.71 & 133 & 3342.10 & L. Es3 & 0.51 \\
\hline 64 & 3111.70 & Es3 & 0.80 & 134 & 3353.00 & L. Es3 & 0.53 \\
\hline 65 & 3125.60 & Es3 & 0.60 & 135 & 3356.20 & L. Es3 & 0.57 \\
\hline 66 & 3134.50 & Es3 & 0.51 & 136 & 3357.60 & L. Es3 & 0.54 \\
\hline 67 & 3141.20 & Es3 & 0.46 & 137 & 3364.50 & L. Es3 & 0.75 \\
\hline 68 & 3158.20 & Es3 & 0.59 & 138 & 3365.80 & L. Es3 & 0.59 \\
\hline 69 & 3171.00 & Es3 & 0.63 & 139 & 3366.93 & Es3 & 0.39 \\
\hline 70 & 3183.72 & Es3 & 0.45 & 140 & 3367.50 & L. Es3 & 0.74 \\
\hline
\end{tabular}

3.3. Relationship Between the Change of Element Ratios and High-Frequency Sequence Stratigraphy Division in Shale

Previous studies on the high-frequency sequence division of the lake strata mainly applied to the coarse debris depositional system. Because of its obvious lithologic changes, it is easy to recognize the progradational and retrogradational changes in the sediment deposition process. However, for shale in a deep water deposition system, due to the lack of obvious cyclicity changes in lithology, the division of its sequence (especially highfrequency sequence) is difficult. This study attempts to divide the high-frequency sequence of fine-grained sediments in deep water (shale) by the element ratios and the changes of the sedimentary environment associated with the element ratios.

The different elements and element ratios in sediments reflect different sedimentary environments of mudstone, such as the distance from the shore, the depth of the lake, and the conditions of the water medium. The sedimentary environment of shale is closely related to the change in high-frequency sequence. For example, generally, the deepening of 
lake water responds to the base level rising, which is identified as a transgression sequence. The sudden transgression and retrogression of the lake may leave traces in the strata, that is, the change of the elements. Therefore, the element phase can indicate the change of the sequence. According to the changes of the sedimentary environment indicated by the ratio of elements, the sequence division of the shale profile can be carried out.

As mentioned above, during the process of lake basin evolution, depositional facies change from salt lake to blocked lake, open lake, and then delta; as the sediment transport distance decreases, the water salinity of the ancient water body becomes lighter, the $\mathrm{PH}$ value decreases, the Eh value increases, the performance is gradually reduced by $\mathrm{Sr} / \mathrm{Ba}$ and $\mathrm{Ca} / \mathrm{Mg}$ ratios, and the $\mathrm{Rb} / \mathrm{Ca}$ and $\mathrm{Fe} / \mathrm{Mn}$ ratios increase. According to changes of elements, combined with data available in this study, we concluded that ratios $\mathrm{Sr} / \mathrm{Ba}$ and $\mathrm{Ca} / \mathrm{Mg}$ near the sequence boundary are low, and ratios of $\mathrm{Fe} / \mathrm{Mn}$ and $\mathrm{Rb} / \mathrm{Ca}$ ratios are high. In addition, the $\mathrm{Sr} / \mathrm{Ba}$ and $\mathrm{Ca} / \mathrm{Mg}$ ratios near the flooding surface are high, and ratios of $\mathrm{Fe} / \mathrm{Mn}$ and $\mathrm{Rb} / \mathrm{Ca}$ ratios are low (Figure 4). This conclusion provided an important theoretical basis for the division of high-frequency sequences in lacustrine shale and also provides new research ideas for the division of high-frequency sequences' stratigraphy in marine shale. The conclusion is of great importance for the evaluation and development of oil and gas resources in shales.

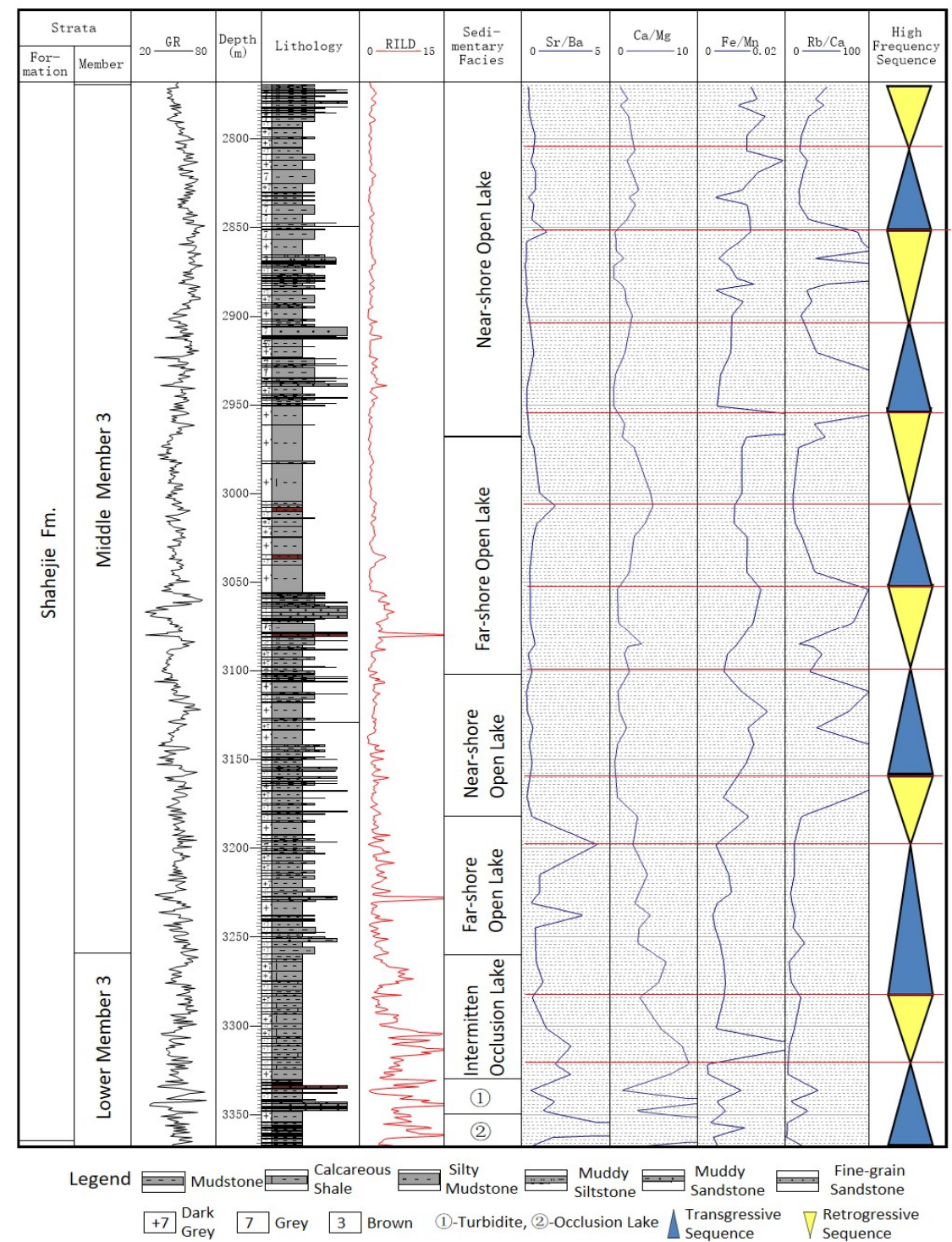

Figure 4. The element ratio of the shale and high-frequency sequence division in Well Niu 38 of Dongying Depression. 


\section{Conclusions}

(1) During the evolution of the lake basin, the depositional environment changes from salt lake to blocked lake, open lake, and finally delta. As the decrease of sediment transport, the salinity of the ancient water becomes lighter, and the element ratio also changes accordingly. Especially, during the above evolution, the $\mathrm{Sr} / \mathrm{Ba}$ and $\mathrm{Ca} / \mathrm{Mg}$ ratios increase, and the $\mathrm{Rb} / \mathrm{Ca}$ and $\mathrm{Fe} / \mathrm{Mn}$ ratios are increased.

(2) The content of organic matter is high in occluded lake facies, intermittent lake facies, and open lake facies mudstone. Organic matter preservation can be damaged when the water depth becomes shallower, the hydrodynamic energy increases, and the reduction conditions become weaker. The stratification of lake water is beneficial for organic matter accumulation and preservation.

(3) The element geochemical ratios can be used for high-frequency sequence stratigraphic division of lacustrine shale. The $\mathrm{Sr} / \mathrm{Ba}$ and $\mathrm{Ca} / \mathrm{Mg}$ ratios near the sequence boundary are low and the $\mathrm{Fe} / \mathrm{Mn}$ and $\mathrm{Rb} / \mathrm{Ca}$ ratios are high, while the $\mathrm{Sr} / \mathrm{Ba}$ and $\mathrm{Ca} / \mathrm{Mg}$ ratios near the flooding surface are high and the $\mathrm{Fe} / \mathrm{Mn}$ and $\mathrm{Rb} / \mathrm{Ca}$ ratios are low. The relationship between those element ratios and high-frequency sequences is initially established in the lake shale profile.

Supplementary Materials: The following are available online at https: / www.mdpi.com/article / $10.3390 / \min 11060657 / s 1$, Table S1: Element contents and element ratios of shale in different wells, Dongying Depression.

Author Contributions: conceptualization, H.W.; methodology, H.W.; software, Z.Z.; validation, H.W., Z.Z. and J.L.; formal analysis, H.W. and Z.Z.; investigation, Z.Z. and J.L.; resources, H.L.; data curation, S.S.; writing-original draft preparation, H.W.; writing-review and editing, H.W. and Z.Z.; supervision, H.L. and S.S.; project administration, H.W.; funding acquisition, H.L. and S.S. All authors have read and agreed to the published version of the manuscript.

Funding: This work is supported by the Fundamental Research Funds for the Central Universities of China (No. 2652017323) and the National Science and Technology Major Project (Grant No. 2016ZX05033).

Acknowledgments: Our thanks go to the Shengli Oilfield Company of the SINOPEC Group for their support in sample collection and rock core observation.

Conflicts of Interest: The authors declare no conflict of interest.

\section{References}

1. Macquaker, J.H.S.; Gawthorpe, R.L. Mudstone Lithofacies in the Kimmeridge Clay Formation, Wessex Basin, Southern England: Implications for the Origin and Controls of the Distribution of Mudstones: REPLY. J. Sediment. Res. 1993, 63, $1129-1143$.

2. Montgomery, S.L.; Jarvie, D.M.; Bowker, K.A.; Pollastro, R.M. Mississippian Barnett Shale, Fort Worth basin, north-central Texas: Gas-shale play with multi-trillion cubic foot potential. AAPG Bull. 2005, 89, 155-175. [CrossRef]

3. Liu, Z.J.; Meng, Q.T.; Liu, R. Characteristics and genetic types of continental oil shales in China. J. Palaeogeogr. 2009, 11, 105-114.

4. Li, Y.X.; Nie, H.K.; Long, P.Y. Development characteristics of organic-rich shale and strategic selection of shale gas exploration area in China. Nat. Gas Ind. 2009, 29, 115-118.

5. Loucks, R.G.; Ruppel, S.C. Mississippian Barnett Shale: Lithofacies and depositional setting of a deep-water shale-gas succession in the Fort Worth Basin, Texas. AAPG Bull. 2007, 91, 579-601. [CrossRef]

6. Wang, G.; Liang, G. Identification of Aeolian Silty Sand in Lacustrine Shale of the Shahejie Formation in the Jiyang Depression and Its Indication to Paleoclimate. Acta Geol. Sin. 2007, 81, 413-418.

7. Liu, C.; Shu, X.; Liu, Z. Micro-characteristics of Paleogene lacustrine petroleum source rocks in Jiyang depressio. Acta Sedimentol. Sin. 2001, 19, 293-298.

8. Wignall, P.B. Mudstone Lithofacies in the Kimmeridge Clay Formation, Wessex Basin, Southern England: Implications for the Origin and Controls of the Distribution of Mudstones: Discussion and reply. J. Sediment. Res. 1994, 64, 927-929. [CrossRef]

9. Macquaker, J.H.S. A lithofacies study of the Peterborough Member, Oxford Clay Formation (Jurassic), UK: An example of sediment bypass in a mudstone succession. J. Geol. Soc. Lond. 1994, 151, 161-172. [CrossRef]

10. Deng, H.; Qian, K. Sedimentary Geochemistry and Environment Analysis; Gansu Science and Technology Press: Lanzhou, China, 1993.

11. Kulpecz, A.A.; Miller, K.G.; Sugarman, P.J.; Browning, J.V. Response of late cretaceous migrating deltaic facies systems to sea level, tectonics, and sediment supply changes, New Jersey coastal plain, USA. J. Sediment. Res. 2008, 78, 112-129. [CrossRef] 
12. Flocks, J.G.; Ferina, N.F.; Dreher, C.; Kindinger, J.L.; Fitzgerald, D.M.; Kulp, M.A. High-Resolution Stratigraphy of a Mississippi Subdelta-Lobe Progradation in the Barataria Bight, North-Central Gulf of Mexico. J. Sediment. Res. 2006, 76, 429-443. [CrossRef]

13. Pietras, J.T.; Carroll, A.R. High-resolution sequence stratigraphy and strontium isotope geochemistry of Lacustrine Wilkins Peak Member, Eocene Green River Formation, Wyoming, U.S.A. J Sediment. Res. 2006, 76, 1197-1214. [CrossRef]

14. Janok, P.; Bhattacharya, B.J.W. Lowstand deltas in the Frontier Formation, Powder River basin, Wyoming: Implications for sequence stratigraphic models. AAPG Bull. 2001, 85, 261-294.

15. Williams, C.J.; Hesselbo, S.P.; Jenkyns, H.C.; Morgans Bell, H.S. Quartz silt in mudrocks as a key to sequence stratigraphy (Kimmeridge Clay Formation, Late Jurassic, Wessex Basin, UK). Terra Nova 2001, 13, 449-455. [CrossRef]

16. Bohacs, K.M. Contrasting expressions of depositional sequences in mudrocks from marine to non marine environs. In Shales and Mudstones: Recent Progress in Shale Research; Schieber, J., Zimmerle, W., Sethi, P.S., Eds.; Schweizerbart'sche Verlagsbuchhandlung: Stuttgart, Germany, 1988; pp. 33-78.

17. Macquaker, J.H.S.; Taylor, K.G. A sequence-stratigraphic interpretation of a mudstone-dominated succession: The Lower Jurassic Cleveland Ironstone Formation, UK. J. Geol. Soc. Lond. 1996, 153, 759-770. [CrossRef]

18. Vidier, J.P.H.A. Sequence stratigraphy of source rocks applied to the study of the Kim meridgian/Tithonian in the north-west European shelf (Dorset/UK, Yorkshire/UK and Boulonnais/France). Mar. Petrol. Geol. 1995, 12, 177-194.

19. Stephen, C.; Passe, Q.R. Recurring Patterns of Total Organic Carbon and Source Rock Quality within a Sequence Stratigraphic Framework. Bulletin 1993, 77, 386-401.

20. Bohacs, K.L.R. Sequence stratigraphy in fine-grained rocks at the field to flow-unit scale: Insights for correlation, mapping, and genetic controls. In Proceedings of the Applied Geoscience Conference (AGC), Houston, TX, USA, 8 February 2010.

21. May, J.A.; Anderson, D.S. Mudrock reservoir deposition and stratigraphy: Not homogenous, not boring. In Proceedings of the AAPG/SEG/SPE/SPWLA Hedberg Conference "Critical Assessment of Shale Resource Plays", Houston, TX, USA, 5-10 December 2010.

22. $\mathrm{Wu}$, J.; Jiang, Z.; Tong, J.; Yang, L.; Nie, H. Sedimentary environment and control factors of fine-grained sedimentary rocks in the upper fourth Member of Paleogene Shahejie Formation, Dongying sag. Acta Pet. Sin. 2016, 37, 464-473.

23. Li, Y.F.; Shao, D.Y.; Lv, H.S.; Zhang, Y.; Zhang, X.L.; Zhang, T.W. A relationship between elemental geochemical characteristics and organic matter enrichment in marine shale of Wufeng Formation-Longmaxi Formation, Sichuan Basin. Acta Pet. Sin. 2015, $36,1470-1483$.

24. Guo, L.Y.; Zhong-Sheng, L.I.; Xie, X.N.; Shang, F.; Fan, Z.H.; Liu, Z.J.; Feng, W.U. High-frequency Variation of Geochemical Elements and Its Geological Implication on Lacustrine Organic-rich Mudstone and Shale Formation: An Example from the Core-taking Segment of Well BY1 in the Biyang Depression. Geoscience 2015, 29, 1360-1370.

25. Jin, F.M.; Han, C.Y.; Wang, J.M.; Guo, Y.J.; Gao, Z.H. Application of Organic Geochemical parameters in sequence classification and correlation: A case study from Lower Es3 in Shulu Sag, Jizhong Depression. Acta Sedimentol. Sin. 2008, 26, 86.

26. Zhang, L.; Li, Z.; Zhu, R. Resource potential of shale gas in paleogene in jiyang depression. Nat. Gas Ind. 2008, $28,26-29$.

27. Liu, X.M.; Wang, S.J.; Sun, C.X.; Jia, Y.H.; Li, T.Y. Strontium as an essential indicator of paleosalinity. Acta Mineral. Sin. 2000, 20, 91-96.

28. Dedeckker, P.; Last, W.M. Modern dolomite deposition in continental, saline lakes, western Victoria, Australia. Geology 1988, 16, 29-32. [CrossRef]

29. Nelson, C.H. Sediments of Crater Lake, Oregon. GSA Bull. 1967, 78, 833. [CrossRef] 